\title{
PILIHAN KODE DALAM INTERAKSI BELAJAR-MENGAJAR DI PESANTREN (KAJIAN SOSIOLINGUISTIK)
}

\author{
Eka Susylowati \\ Sastra Inggris, Universitas Surakarta \\ Jalan Raya Palur Km 5, Surakarta \\ Pos-el: esusylowati@gmail.com
}

\begin{abstract}
Abstrak
Keanekaragaman bahasa yang digunakan oleh masyarakat santri dapat merepresentasikan adanya masyarakat multietnik dan multilingual. Tujuan penelitian ini mengungkapkan pilihan kode dalam interaksi belajar-mengajar antarasantri dan sa ntri, santri dan ustazah di Pesantren Islam Al-Mukmin Ngruki dan Pesantren Modern Islam Assalaam. Penelitian ini termasuk penelitian deskriptif kualitatif dengan menggunakan pendekatan sosiolinguistik. Pengumpulan data menggunakan metode observasi, rekaman, dan wawancara. Data dalam penelitian ini berupa tuturan santri di lingkungan pesantren.Data dianalisis dengan menggunakan metode etnography communication Hymes. Hasil penelitian ini menunjukkan bahwa terdapat variasi kode yang digunakan oleh santri wanita yaitu bahasa Indonesia (BI), bahasa asing (BA), bahasa Jawa (BJ), dan bahasa campur (BC) berupa alih kode dan campur kode yaitu dari bahasa Jawa ke dalam bahasa Indonesia, campur kode bahasa Jawa ke dalam bahasa Inggris.
\end{abstract}

Kata Kunci: pilihan kode, interaksi belajar-mengajar, pesantren

Language Choice in the Interaction in Learning and Teaching Activity in Islamic Boarding School (A Study of Sociolinguistics)

\begin{abstract}
The diversity of languages used by santri (student) community can represent the existence of multi-ethnic and multilingual communities. The purpose of this study is to reveal the language choice in teaching and learning interactions between students and students with teacher in AlMukmin Ngruki Islamic Boarding School and Assalaam Modern Islamic Boarding School. This research is a qualitative descriptive study using the Sociolinguistics approach. Data collected used the method of observation, recording, and interviews. The data in this study was in the form of student speech in an Islamic boarding school. The data were analyzed using the Hymes ethnography communication method. The results of this study indicate that there are variations in the codes used by students, namely Indonesian, foreign languages, Javanese, and mixed languages in the form of code-switching and code mixing from Javanese to Indonesian, and Javanese to English.
\end{abstract}

Keywords: language code, learning-teaching interaction, Islamic boarding school,

\section{PENDAHULUAN}

Pesantren memiliki nilai plus tersendiri dibandingkan dengan pendidikan umum karena dalam lingkungan pesantren menyeimbangkan antara materi pendidikan formal dengan materi diniyah atau keagamaan yang lebih mendalam. Dalam dekade terakhir ini, pesantren mengalami peningkatan yang luar biasa dan menakjubkan, baik pesantren yang terletak di wilayah pedesaan, pinggiran kota, maupun perkotaan. Data Kementerian Agama menyebutkan bahwa data terakhir tahun 2016 menunjukkan pesantren sebanyak 28.961 lembaga dengan santri sebanyak 4.028.660 jiwa. Peran santri sangat penting dari zaman ke zaman, santri ikut andil dalam mengelaborasi, mempertemukan antara ilmu Islam murni dan ilmu pengetahuan. Dalam konteks dalam kehidupan manusia memerlukan arah dan pedoman sehingga kita harus 
berpegang teguh kepada agama atau kepercayaan masing-masing, sedangkan manusia untuk berkembang perlu ilmu pengetahuan.

Santri di lingkungan Pesantren Islam Al-Mukmin Ngruki menggunakan berbagai variasi bahasa dalam interaksi komunikasi. Bahasa yang wajib dipelajari di pesantren yaitu bahasa Indonesia, bahasa Inggris, bahasa Arab. Pesantren Islam Al-Mukmin Ngruki memiliki aturan melarang santrinya menggunakan bahasa daerah dalam komunikasi, tetapi para santri banyak yang melanggar aturan tersebut, kadang dalam komunikasi lisan mereka menggunakan bahasa daerah apabila sudah akrab dengan temannya yang berasal dari daerah yang sama. Pada saat situasi formal, seperti dalam interaksi belajar-mengajar, kode yang sering digunakan yaitu kode bahasa Indonesia (BI), bahasa Asing (bahasa Inggris dan bahasa Arab), serta bahasa Jawa (BJ). Selanjutnya, dalam situasi informal pilihan kode bahasa Indonesia, bahasa Arab, bahasa Inggris, dan bahasa Jawa, serta bahasa Melayu dan bahasa Sunda digunakan sebagai media komunikasi antarsantri di lingkungan Pesantren Modern Islam Assalaam dan Pesantren Islam Al-Mukmin Ngruki.

Pesantren Islam Al-Mukmin Ngruki merupakan pesantren tradisional-modern di Indonesia yang para santrinya berasal dari multietnik seperti Jawa, Kalimantan, Lampung, Sulawesi, Sunda, Jambi. Penggunaan bahasa asing (Inggris dan Arab) dalam pesantren untuk meningkatkan kualitas berbahasa santri. Hal ini dapat membentuk karakter berbahasa santri agar terbiasa menggunakan bahasa asing dan bahasa Indonesia dalam interaksi komunikasi di dalam pesantren maupun di luar pesantren, sedangkan Pesantren Modern Islam
Assalaam merupakan pesantren modern yang santrinya multilingual. Selain itu, santrinya juga berasal dari berbagai etnis yaitu etnis Jawa (56\%), etnis Melayu (12\%), etnis Banjar (9\%), etnis Sunda (20\%), dan terdapat santri yang tinggal di Negara Malaysia, Thailand, Arab, dan lain sebagainya.

Penelitian mengenai pilihan kode merupakan kajian yang banyak diminati oleh ahli bahasa. Penelitian mengenai kode sebelumnya pernah dilakukan oleh Darmawati (2013) yang berjudul Alih Kode dalam Konteks Percakapan Guru di MAN Makassar yang dimuat dalam Jurnal Kandai. Penelitian ini mengungkapkan bentuk-bentuk pilihan kode dalam percakapan guru-guru di MAN 3 Makassar, topik yang memengaruhi alih kode dan frekuensinya. Hasil penelitian menunjukkan bahwa alih kode dalam percakapan guru-guru di MAN 3 Makasar tersebut muncul pada saat situasi informal. Penutur menggunakan bahasa Indonesia dialek Makasar dengan ditandai adanya klitika $k o, k i, m i$, klitika kepunyaan $t a$, morfem yang berbentuk silabik $d i$, serta penggunaan kata edede, kapang, dan beng. Terdapat sepuluh topik yang digunakan dalam percakapan tersebut, antara lain mengenai golongan dan kepangkatan, perincian gaji, pengembalian buku latihan, bertanya, pemilihan umum, pembagian kalender, baju seragam, konsultasi jurusan, kemampuan bahasa Inggris, dan masakan. Selanjutnya, frekuensi penggunaan alih kode dalam percakapan guru-guru di MAN 3 Makasar sangat tinggi karena dipengaruhi oleh situasi informal. Penelitian ini berkaitan karena sama-sama bertujuan mengungkapkan pilihan kode dan faktor yang mempengaruhi pilihan kode, hanya saja perbedaannya terletak pada lokasi penelitian. 
Eka Susylowati: Pilihan Kode dalam Interaksi Belajar-Mengajarsebagai Upaya Meningkatkan Kesepahaman Antaretnik

Sa'adiah Ma'alip (2015) pernah melakukan penelitian dengan judul Pemilihan Bahasa dalam Komunikasi di Laman Sosial. Hasilnya menunjukkan bahwa pola pemilihan bahasa yang digunakan di laman sosial yaitu untuk tujuan komunikasi yang berlainan yaitu bahasa Melayu dan bahasa Inggris yang menjadi pilihan utama. Persamaan dengan penelitian ini adalah sama-sama mengkaji pilihan bahasa, sedangkan perbedaanya adalah penelitian yang dilakukan oleh Ma'alip mengkaji pilihan bahasa di laman sosial sedangkan penelitian ini mengkaji pilihan kode di lingkungan pesantren.

Harun \& Yusof, (2015) dalam jurnal Komunikasi (Malaysian Journal of Communication) yang berjudul Komunikasi Bahasa Melayu-Jawa dalam Media Sosial. Hasil penelitian mendeskripsikan bahwa penggunaan bahasa Jawa digunakan sepenuhnya dalam suatu percakapan dan kadang terjadi peralihan dengan menggunakan bahasa Melayu dalam media sosial. Penguasaan kedua bahasa yang baik dalam penutur bahasa Jawa menjadikan lebih mudah untuk peralihan kode yaitu bahasa Jawa ke dalam bahasa Melayu dan bahasa Melayu ke dalam bahasa Jawa. Penelitian Maros, Mohd Noorizan, \& Zakaria (2016) dengan judul Code Switching as the Medium of Solidarity in "Ola Bola". Penelitiannya menunjukkan bahwa penggunaan peralihan kode boleh menggambarkan semangat kekitaan, patriotisme serta perpaduan di dalam sebuah masyarakat majemuk dari perspektif Malaysia secara keseluruhannya. Penelitian tersebut lebih difokuskan pada film yang tentunya berbeda dengan penelitian ini yang memusatkan di lingkungan pesantren dalam ranah pendidikan.
Mustikawati (2016) dalam penelitiannya dengan judul Code-Mixing and Code Switching in The Process of Learning mengambil lokasi di Pondok Pesantren Al Mawaddah di Ponorogo. Hasil penelitian ini menunjukkan bahwa wujud campur kode dan alih kode kegiatan pembelajaran di Pondok Pesantren Al Mawaddah adalah peralihan penggunaaan bahasa baik bahasa Jawa, bahasa Arab, bahasa Inggris, dan bahasa Indonesia, pada penggunaan penyisipan kata, frasa, idiom, penggunaan katabenda, kata sifat, klausa, dan kalimat. Dari penelitian ini, ditemukan keterkaitan antara penggunaan alih kode dalam proses pembelajaran di kelas untuk memudahkan santri dalam menerima pembahasan yang disampaikan.

Penelitian yang sama pernah dilakukan oleh Wahidah, Djatmika, \& Marmanto (2017) dengan judul Pilihan Kode bagi Siswa di Pesantren Ulil Albab (Kajian Sosiolinguistik). Hasil penelitian menyatakan bahwa pilihan kode bahasa yang digunakan oleh siswa dalam aktivitas sehari-hari di lingkungan Pesantren Ulil Albab yaitu Indonesia, Sasak, Arab, dan Inggris. Pemilihan kode lebih banyak dilakukan pada jenis conversational yang sesuai dengan konteks pembahasan yang disampaikan oleh penutur. Penggunaan dialek Selarapang yang selalu dipergunakan oleh para guru sehingga penggunaan bahasa Sasak tidak terlepas dari penggunaan alih kode pada saat pembelajaran di kelas.

Mutmainah (2008) dalam tesisnya melakukan penelitian mengenai pemilihan kode dengan judul Pemilihan Kode dalam Masyarakat Dwibahasa: Kajian Sosiolinguistik pada Masyarakat Jawa di Kota Bontang Kalimantan Timur, menjelaskan bahwa kode yang berwujud bahasa yang dominan digunakan dalam 
interaksi komunikasi masyarakat Jawa di Kota Bontang meliputi bahasa Indonesia (BI), bahasa Jawa (BJ), bahasa daerah lain (BL), bahasa Asing (BA). Peristiwa alih kode dan campur kode dalam masyarakat tutur Jawa di kota Bontang dapat diklasifikasikan dalam dua variasi, yaitu (1) alih kode dan campur kode dengan dasar BI dan (2) alih kode dan campur kode dengan dasar BJ. Faktor-faktor penentu alih kode yaitu (1) perubahan situasi tutur, (2) kehadiran orang ketiga, (3) peralihan pokok pembicaran. Sedangkan penentu campur kode terjadi karena dipengaruhi duafaktor yaitu (1) keterbatasan penggunaan kode dan (2) penggunaan istilah yang lebih populer.

Penelitian yang telah dilakukan oleh Maryam (2019) menunjukkan bahwa terdapat alih kode, campur kode, dan interferensi. Alih kode terdiri atas alih kode ke dalam dan alih kode keluar. Alih kode ke dalam ditemukan alih kode bahasa Indonesia ke bahasa Ambon atau bahasa Jawa. Alih kode ke luar berupa alih kode bahasa Indonesia ke bahasa Inggris atau bahasa Arab, sedangkan campur kode terdiri atas tiga bentuk yaitu campur kode ke dalam (bahasa Jawa dan Betawi), campur kode luar (bahasa Inggris dan Arab), dan campur kode campuran (bahasa Inggris, bahasa Arab, dan bahasa Jawa). Faktor-faktor yang memengaruhi munculnya alih kode dan campur kode karena adanya peralihan pokok pembicaraan, penggunaan ragam nonformal, tutur bahasa rendah, keterbatasan padanan kata, dan penggunaan istilah yang lebih populer. Selain itu, hasil penelitian juga menunjukkan adanya interferensi pada tataran morfologi hal ini dipengaruhi faktor kebiasaan penggunaan bahasa ibu. Penelitian ini relevan dengan hasil penelitian Maryam karena sama-sama bertujuan mengungkapkan pola bahasa dan faktor-faktor yang mempengaruhi. Perbedaan dengan penelitian ini terletak pada sasaran, yaitu penelitian yang dilakukan oleh Maryam objeknya adalah novel, sedangkan penelitian ini sasarannya yaitu para santri dan ustazah, santri dengan santri pada saat interaksi belajar-mengajar di lingkungan peantren. Dalam konteks ini, pilihan kode dapat digunakan sebagai strategi untuk memudahkan komunikasi dan mengefektifkan dalam proses belajarmengajar di lingkungan Pesantren Modern Islam Assalaam dan Pesantren Islam AlMukmin Ngruki. Pilihan suatu bahasa, dalam konteks ini bahasa Indonesia (BI), bahasa Inggris (B.Ing), bahasa Arab (bAr), dan bahasa Jawa (BJ) dapat mengakibatkan salah satu bahasa tersebut mengalami pergeseran. Oleh karena itu, peneliti ingin mengkaji lebih dalam mengenai pilihan kode dalam pesantren, khususnya saat proses interaksi belajar-mengajar pada ranah pendidikan. Dalam penelitianini difokuskan pada pilihan kode yaitu bahasa Indonesia, bahasa asing (bahasa Inggris dan bahasa Arab), bahasa Jawa dalam ranah pendidikan. Ranah tersebut dipilih karena merupakan ranah yang paling penting sebagai pemertahanan bahasa ibu.

\section{TEORI}

Penelitian Sosiolinguistik tentang pilihan kode telah banyak dilakukan sebelumnya antara lain (Sabti, Rashid, \& Turki, 2019), (Faiz, 2018), (Thesa, 2017), (Khaerunnisa, 2016), (Jaafar, Awal, Mis, \& Lateh, 2016), (Halim \& Maros, 2014), (Al-hourani \& Afizah, 2013), (Sayama Malabar, 2012) penelitian pilihan kode masih terbatas pada penggunaan seperti ceramah, sekolah umum, film, novel, talkshow, sosial media. Tujuan dari pilihan kode yaitu menemukan 
Eka Susylowati: Pilihan Kode dalam Interaksi Belajar-Mengajarsebagai Upaya Meningkatkan Kesepahaman Antaretnik

jenis pilihan kode dan faktor-faktor yang mempengaruhi pilihan kode. Oleh karena itu, peneliti mendapatkan gap research melakukan penelitian pilihan kode dalam interaksi belajar-mengajar di lingkungan Pesantren Islam Al-Mukmin Ngruki dan Pesantren Modern Islam Assalaam. Hal ini bertujuan untuk menemukan pola pilihan kode dalam interaksi belajar-mengajar di lingkungan Pesantren Modern Islam Assalaam dan Pesantren Islam Al-Mukmin Ngruki.

Menurut kajian Sosiolinguistik, pilihan kode dalam masyarakat multietnik dan multibahasa merupakan gejala yang sangat menarik untuk dikaji. Masyarakat santri di lingkungan Pesantren Islam AlMukmin Ngruki dan Pesantren Modern Islam Assalaam di Indonesia memiliki bahasa pertama yang berbeda-beda sesuai dengan asal daerah santri masing-masing, sehingga dapat mengakibatkan kontak bahasa. Selain itu, terjadi kontak bahasa dengan santri yang lain yang berbeda bahasa dengan mereka. Hal ini dapat mengakibatkan terjadinya pilihan kode yang digunakan untuk interaksi komunikasi dalam proses belajar-mengajar di lingkungan Pesantren Islam Al-Mukmin Ngruki dan Pesantren Modern Islam Assalaam.

Sosiolinguistik merupakan ilmu antardisiplin antara sosiologi dengan linguistik, dua bidang ilmu empiris yang mempunyai kaitan erat. Sosiologi merupakan kajian yang objektif dan ilmiah mengenai manusia di dalam masyarakat, lembaga- lembaga, dan proses sosial yang ada di dalam masyarakat. Kajian Sosiologi berusaha untuk mengetahui bagaimana masyarakat itu terjadi, berlangsung, dan tetap ada. Dengan mempelajari lembagalembaga, proses sosial dan segala masalah sosial di dalam masyarakat, akan diketahui cara-cara manusia menyesuaikan diri dengan lingkungannya, bagaimana mereka bersosialisasi, dan menempatkan diri dalam tempatnya masing-masing di dalam masyarakat. Sementara itu, linguistik adalah bidang ilmu yang mempelajari tentang bahasa, atau ilmu yang mengambil bahasa sebagai objek kajiannya. Dengan demikian, dapat dikatakan bahwa sosiolinguistik adalah bidang ilmu antardisipliner yang mempelajari bahasa dalam kaitannya dengan penggunaan bahasa itu dalam masyarakat (Abdul, 2003). Dari uraian diatas, dapat disimpulkan bahwa sosiolinguistik adalah antardisipliner yang mempelajari bahasa dalam kaitannya dengan bahasa yang digunakan dalam lingkungan tersebut.

\section{Variasi Bahasa}

Pada kenyataannya bahasa adalah kaya raya dengan keanekaragaman perwujudannya. Alwasilah (1985) dalam (Suandi, 2014) mengungkapkan bahwa perwujudan bahasa itu sangat luasnya sehingga variasi-variasi itu seakan tanpa batas. Keanekaragaman bahasa itu tidak hanya ditentukan oleh faktor-faktor linguistik, tetapi juga oleh faktor-faktor nonlinguistik, termasuk faktor sosial. Faktor-faktor sosial itu mencakup: status sosial, tingkat pendidikan, umur, tingkat ekonomi, jenis kelamin, dan sebagainya. Adapun faktor situasional yang mempengaruhi keragaman bahasa mencakup siapa berbicara kepada siapa, kapan, dimana, dan mengenai apa, yang secara ringkas dirumuskan oleh Fishman sebagai "who speaks what language to whom and when" Pride and Holmes, 1972 dalam (Suandi, 2014). Dalam konteks ini, penggunaan bahasa di lingkungan pesantren bergantung kepada siapa berbicara, dimana, dan kapan. Di 
lingkungan pesantren, pilihan kode bahasa Indonesia masih dominan digunakan oleh santri saat berkomunikasi dengan ustazah baik di dalam kelas maupun di luar kelas pada saat situasi formal maupun informal. Di sisi lain, penggunaan bahasa asing (Inggris dan Arab) sudah menjadi aturan yang wajib digunakan sebagai komunikasi di pesantren. Bahasa daerah (bahasa Jawa) digunakan untuk menjalin keakraban antarsantri. Misalnya, ketika santri berbicara dengan ustazah menggunakan bahasa Inggris atau bahasa Arab atau menggunakan bahasa Indonesia, sedangkan ketika berkomunikasi kepada sesama mereka menggunakan bahasa Indonesia informal, bahasa asing (Inggris atau Arab), dan bahasa daerah (bahasa Jawa) baik dalam situasi formal maupun informal.

Ferguson dalam (Wardhaugh, 2006) memberikan definisi tentang variasi bahasa sebagai berikut.

"Any body of human speech patterns which is sufficiently homogeneous to be analyzed by available techniques of synchronic description and which has a sufficiently large repertory and elements of their arrangements or processes with broad enough semantic scope to function in all normal contexts of communication."

Dari definisi tersebut, dapat dilihat bahwa ada pola-pola bahasa yang sama (homogeneous). Pola-pola bahasa itu dapat dianalisis secara deskriptif dan pola-pola yang dibatasi oleh makna tersebut dipergunakan oleh penuturnya dalam semua konteks komunikasi yang wajar. Nababan (1984) dalam (Suandi, 2014) membagi variasi bahasa berdasarkan sumber perbedaan, yaitu (1) variasi internal (variasi sistemik), dan (2) variasi eksternal (variasi ekstrasistemik). Variasi internal adalah variasi yang disebabkan oleh faktor-faktor dalam bahasa itu sendiri, misalnya bunyi /p/ yang bervariasi antara yang aspirated dan tidak aspirated dalam bahasa Inggris. Adapun variasi eksternal adalah variasi yang berhubungan dengan faktor-faktor di luar sistem bahasa itu sendiri. Dalam hal ini dialek, fungsiolek, dan sosiolek termasuk dalam jenis variasi eksternal.

\section{Pilihan Kode}

Dalam masyarakat bilingual atau multilingual dapat memunculkan adanya berbagai bahasa atau variasi bahasa dalam masyarakat. Dalam berkomunikasi, seseorang melakukan pilihan mengenai variasi bahasa yang sesuai ketika berinteraksi dengan mitra tuturnya yang berasal dari lapisan tingkatan yang berbeda-beda. Dalam interaksi sosial, masalah pilihan bahasa sebagai pokok permasalahan sosial yang tampak dalam masyarakat multilingual. Sebagaimana, dalam suatu topik pembicaraan tertentu, secara langsung maupun tidak langsung dapat memungkinkan terjadinya satu variasi bahasa dipilih untuk digunakan daripada variasi bahasa lainnya.

Pilihan bahasa dapat dipengaruhi berbagai faktor sosial, (Holmes, 2001) mengatakan faktor sosial yang dapat menentukan pemilihan bahasa dalam percakapan meliputi mitra tutur, konteks sosial dari sebuah percakapan, serta topik percakapan. Pemilihan bahasa dalam masyarakat multilingual sangat menarik untuk diteliti dengan perspektif Sosiolinguistik karena bahasa tidak hanya berkaitan sebagai sistem tanda saja, tetapi juga berkaitan dengan sistem sosial, komunikasi, dan erat kaitannya dengan budaya masyarakat tertentu. Dalam kajian bahasa, dengan menggunakan perspektif sosiolinguistik akandipertimbangkan 
Eka Susylowati: Pilihan Kode dalam Interaksi Belajar-Mengajarsebagai Upaya Meningkatkan Kesepahaman Antaretnik

bagaimana penggunaannya dalam masyarakat dengan adanya pengaruh dari berbagai faktor sosial dan budaya.

Menurut Fasolddalam (Rokhman, 2013) kajian mengenai pemilihan bahasa dapat dilakukan berdasarkan tiga pendekatan yaitu: pendekatan sosiologi, pendekatan psikologi sosial, dan pendekatan antropologi. Pendekatan sosiologi berkaiatan erat dengan analisis ranah (domain). Konsep ranah dapat digunakan untuk menjelaskan perilaku dalam pemakaian bahasa. Fishman dalam (hlm. 32) memandang sebagai konstelasi faktor-faktor seperti lokasi, topik, dan partisipan. Ranah didefinisikan sebagai konsepsi sosiokultural yang diabstraksikan dari topik komunikasi, hubungan peran antar komunikator, tempat komunikasi di dalam keselarasan lembaga masyarakat dan bagian dari aktivitas masyarakat tutur.

\section{METODE}

Penelitian ini termasuk kajian Sosiolinguistik dengan pendekatan deskriptif kualitatif. Penelitian ini dilakukan untuk mengetahui pilihan kode oleh santri wanita di lingkungan Pesantren Modern Islam Assalaam di Indonesia. Lokasi Pesantren Modern Islam Assalam dipilih karena para santri yang tinggal di dalam asrama Pesantren Modern Islam Assalaam maupun di lingkungan Pesantren Islam Al-Mukmin Ngruki diwajibkan menggunakan dua bahasa asing yaitu bahasa Arab dan bahasa Inggris selama satu tahun dan setelah itu santri wajib menggunakan dua bahasa asing tersebut dalam interaksi komunikasi sehari-hari. Peneliti tertarik untuk meneliti santri di kelas Takhashushiyah karena siswanya sedang mengalami transisi dari sekolah umum pindah ke pesantren sehingga berpengaruh pada pilihan kode.
Santosa (Santosa, mengemukakan bahwa ada dua jenis data yaitu data primer dan data sekunder. Data primer berbentuk tuturan dari para santri wanita yang mengandung pilihan kode pada saat interaksi komunikasi di lingkungan Pesantren Modern Islam Assalaam, sedangkan data sekunder meliputi buku, artikel yang berkaitan dengan penelitian. Metode pengumpulan data dilakukan dengan menggunakan teknik dasar simak, yaitu dengan cara menyimak penggunaan bahasa dalam interaksi belajar-mengajar di lingkungan Pesantren Modern Islam Assalaam dan Pesantren Islam Al-Mukmin Ngruki. Dalam konteks ini, penulis melakukan pengamatan dengan cara observasi ke dalam ruang kelas yaitu mengamati percakapan santri atau siswa dengan ustazah maupun ustaz, santri dan santri. Selanjutnya, peneliti menggunakan metode sadap, dalam hal ini peneliti melakukan penyadapan percakapan antara santri dengan santri maupun santri dengan ustazah atau ustaz, maksudnya peneliti tidak terlibat dalam pembicaraan. Dalam konteks ini, peneliti hanya sebagai pengamat dan tidak terlibat dalam percakapan dan lebih bersifat pasif. Pada tahapan berikutnya dengan teknik lanjutan catat yaitu pencatatan menegani data-data yang berkaitan dengan penelitian yaitu menentukan data-data berupa pilihan kode antara santri dengan santri, santri dengan ustazah maupun ustaz dalam proses belajar-mengajar. Peneliti menggunakan alat bantu perekam.

Dalam bidang linguistik, metode pengumpulan data yang digunakan adalah metode cakap dan metode simak. Dalam metode cakap, banyak digunakan teknik pancing sebagai teknik dasar dan teknik rekam sebagai lanjutannya. Dalam metode 
simak banyak digunakan teknik sadap sebagai teknik dasar, dan teknik catat serta teknik rekam sebagai teknik lanjutannya (Sudaryanto, 2015).

Teknik pengumpulan data pertama yaitu teknik catat yang sebelumnya melalui perekaman. Hal ini dapat pula dilakukan dengan cara pencatatan pada kartu data yang segera dilanjutkan dengan klasifikasi. Teknik catat dapat dilakukan langsung ketika teknik pertama atau teknik kedua selesai dilakukan atau sesudah perekaman dilakukan. Di samping itu, peneliti juga memberikan kuesioner untuk mengetahui identitas dan informasi lain tentang penutur.

Selanjutnya, peneliti mengadakan wawancara dengan informan, di samping merekam yang perlu, peneliti juga mencatat hal-hal yang dikemukakan oleh informan, karena cara ini sangat membantu peneliti jika alat rekam terganggu sekaligus mempercepat proses transkrip yang dilakukan setelah wawancara selesai. Metode kontekstual digunakan untuk menganalisis data mengenai pilihan kode dalam komunikasi santri wanita madrasah takhashushiyyah di lingkungan Pesantren Modern Islam Assalaam dan Pesantren Islam Al-Mukmin Ngruki dengan mengacu pada komponen tutur (Hymes, 2012) yaitu SPEAKING. Tahapan terakhir dalam penelitian ini yaitu menarik simpulan. Hasil simpulan berdasarkan temuantemuan selama peneliti melakukan penelitian di pesantren.

\section{HASIL PENELITIAN DAN \\ PEMBAHASAN}

\section{Bentuk Pilihan Kode}

Pada bagian ini dijelaskan hasil penelitian mengenai pilihan kode dalam interaksi belajar-mengajar di lingkungan Pesantren Modern Islam Assalaam dan Pesantren
Islam Al-Mukmin Ngruki. Secara umum, santri di Pesantren Islam Al-Mukmin Ngruki dapat dikategorikan sebagai masyarakat yang multilingual, artinya mereka menguasai lebih dari dua bahasa. Berdasarkan hasil penelitian, ditemukan bahwa kode-kode yang digunakan oleh santri dalam interaksi komunikasi cukup variatif meliputi kode BI, BA, B.Ing, BABI, BI-BJ.Di bawah ini akan dijelaskan kode-kode yang digunakan dalam interaksi komunikasi antaretnis santri dalam Pesantren Modern Islam Assalam dan Pesantren Islam Al-Mukmin Ngruki pada waktu belajar-mengajar sebagai berikut. Kode bahasa Indonesia selain berfungsi sebagai bahasa Nasional, BI juga bahasa wajib digunakan untuk interaksi komunikasi sehari-hari di pesantren dalam ranah pendidikan antarsantri maupun santri dengan ustazah maupun ustaz. Biasanya kode BI ini digunakan oleh santri wanita pada waktu bertutur dengan santri yang lain yang bukan berasal dari daerah yang sama. Berikut ini hasil penelitian dalam pesantren dalam interaksi belajar-mengajar sebagai berikut.

Konteks tuturan: Pada waktu guru Bahasa Inggris menerangkan materi bahasa Inggris di kelas takhashus pada saat belajar-mengajar. Selain menggunakan bahasa Inggris, guru tersebut juga menggunakan bahasa Indonesia dan bahasa Arab.

\section{Data tuturan (1)}

Ustazah:"Bahasa Inggris juga ada tho nanti, cardinal number sama ordinal number. How many pencil do you have? How many pencil do you have? I have two pencils, tapi kalau kamu tanya...apa nanya ...kamu di kelas mana?...kamu di kamar mana? gitu apa coba!"

Santri : "First...second..." 
Eka Susylowati: Pilihan Kode dalam Interaksi Belajar-Mengajarsebagai Upaya Meningkatkan Kesepahaman Antaretnik

Ustazah: "Iya...very good, ada first, second, third, fourth, the first, the second, ada juga the third, the fourth, the fifth, bahasa Arab juga, iya kan, wahid sama ada al-uula, isnaini dan atsani. Biiayyilughotinnatakallamtunnaf iilkhujuroot.What language do

Santri : (tertawa) you speak in your dorminatory?

Ustazah : "What language do you speak ... Girls? Javanese!

Santri : "Enggak!"

Ustazah :"Sapa yang masih Javanese...ada, masih ada, dulu kan kita sudah deal, dulu kalau yang pake Jawa, kasih apa dari ustazah...apa hadiahnya..di jewer ya. Okey, kembali ke pelajaran.

Percakapan tersebut terjadi di dalam kelas takhassus pada waktu situasi formal antara ustazah dan santri pada waktu pelajaran Bahasa Inggris khususnya grammar.Dalam tuturan di atas, seorang guru atau ustazah merupakan seorang penutur yang bilingual atau multilingual. Hal ini tercermin pada waktu menerangkan bahasa Inggris, guru atau ustazah tersebut menggunakan bahasa Indonesia dan bahasa Arab. Ada beberapa alasan yaitu, pertama, guru atau ustazah tersebut sangat lancar menguasai bahasa Indonesia. Kedua, seorang ustazah di pesantren biasanya dapat menguasai bahasa Asing (Arab) sebagai sumber kajian Islam maupun bahasa Internasional.

Peristiwa tutur secara formal antara ustazah dan santri berada dalam aktivitas belajar-mengajar dengan menggunakan dua atau tiga bahasa. Pada peristiwa tersebut, terdapat istilah bahasa Arab, seperti ustazah ataupun ukhti yang disertakan dalam pembelajaran bahasa Inggris. Dalam konteks sosiolinguistik, apabila terjadi kontak antara dua bahasa maupun tiga bahasa yang dilakukan oleh seorang bilingual maupun multilingul dapat mengakibatkan terjadinya saling pengaruh antar dua bahasa, atau terjadi alih kode dan campur kode, saling pinjam (borrowing), maupun interferensi.

\section{Data tuturan (2)}

Konteks situasi: Percakapan terjadi pada saat proses belajar-mengajar antara guru atau ustazah dengan siswa pada saat pelajaran bahasa Inggris. Guru tersebut memberi pertanyaan kepada siswa mengenai arti kata order.

Ustazah: "Help!help!atau what a nice dress! And the finish, get out of your room, now! If you want to order someone to do something, apa order...order."

Santri : "Memesan."

Ustazah" Memesan....boleh, memesan, selain itu maknanya apa order...meminta orang melakukan sesuatu atau menyuruh. We will order someone to do something, it previous get out if your room, now! Kalau kayak ukhti galau di kamar itu lho."

Peristiwa tutur terjadi dalam aktivitas belajar-mengajar di kelas pada waktu ustadzah menerangkan mata pelajaran bahasa Inggris (writing) khususnya penggunaan kata seru (!), penutur (ustazah) melakukan peralihan bahasa dari bahasa Inggris yang sebelumnya digunakan untuk memberikan penjelasan mengenai topik yang diajarkan yaitu penggunaan kata seru (!), kemudian beralih menggunakan bahasa Indonesia. Penutur (ustazah) memandang bahwa mitra tutur (santri) sudah dapat menyesuaikan diri dengan topik percakapan yang sedang didiskusikan. Peristiwa seperti ini dilakukan oleh ustazah secara natural di Pesantren Modern Islam Assaalam, hal ini dilakukan untuk memudahkan dalam penyampaian materi. Selain itu, terdapat campur kode dalam bahasa Arab, seperti kata ukhti dan variasi populer, kata galau dalam percakapan tersebut. Selanjutnya, pilihan bahasa dapat dilihat dalam cuplikan dialog pada penutur wanita takhashushiyah di pesantren Al-Mukmin Ngruki sebagai berikut. Selain itu, guru sering melakukan pengulangan kata "order". Hal ini 
mempunyai maksud untuk memudahkan siswa dalam pembelajaran bahasa Inggris.

\section{Data tuturan (3)}

Konteks situasi: Percakapan ustazah dengan santri wanita pada saat kegiatan ekstrakurrikuler jurnalistik di lingkungan Pesantren Islam Al-Mukmin Ngruki.

Ustazah: "Hari Minggu besok ada ekstra jurnalistik, apakah tugasnya sudah dikerjakan?"

Santri : "Belum selesai ust, semalam habis mengerjakan PR bahasa Inggris."

Ustazah: "Kalian jadi santri jangan malasmalas, ayo cepetan dikerjakan!"

Santri : "Siap ust.... itu tugasnya seperti mengarang bebas ya ust."

Ustazah: "Iya, kalian membuat cerita tentang liburan kemarin."

Percakapan di atas terjadi di lingkungan Pesantren Islam Al-Mukmin Ngruki antara ustazah dengan santri pada saat situasi informal yaitu pada waktu kegiatan ekstrakurrikuler jurnalistik. Pilihan bahasa Indonesia informal digunakan sebagai media komunikasi. Alasannya digunakan bahasa Indonesia informal untuk memudahkan komunikasi dan menjalin keakraban antara ustazah dengan santrinya. Perlu diketahui di lingkungan Pesantren Islam Al-Mukmin Ngruki mewajibkan untuk mengikuti kegiatan ekstrakurrikuler jurnalistik agar santrinya mampu menulis dan berkarya sebagai jurnalis yang tangguh di masa mendatang.

\section{Data tuturan (4)}

Konteks tuturan: Tuturansantri wanitapada waktu interaksi komunikasi di kelas sebelum pelajaran dimulai.

Santri 1: "Apakah kita harus pakai nametags hari ini?"

Santri 2: "Usually, where do you keep it?" 'Biasanya kamu simpan dimana?'
Santri 1: "Usually, I keep it in lower drawer of locker, but now I don't find it." 'Biasanya saya simpan di laci loker bawah, tetapi sekarang tidak ada.'

Santri 2 :By the way, please check, may be still pinned on the yesterday uniform."

'ntar, coba kamu cek mungkin masih tersemat di baju seragam kemarin.'

Cuplikan percakapan tersebut terjadi antara Santri 1 dan Santri 2 di dalam kelas sebelum interaksi belajar mengajar dimulai di Pesantren Modern Islam Assalaam. Dalam percakapan tersebut, terdapat peristiwa campur kode eksternal yang dilakukan oleh kedua santri wanita madrasah takhashushiyyah yang terjadi di awal percakapan. Peristiwa campur kode eksternal terjadi berupa pergantian pemakaian bahasa Indonesia ke dalam bahasa Inggris. Peristiwa campur kode terjadi dilatarbelakangi kewajiban bagi santri untuk berkomunikasi menggunakan bahasa Inggris. Peristiwa campur kode dalam tuturan di atas dari bahasa Indonesia ke dalam bahasa Inggris. Hal ini tampak pada kata name-tags temasuk kosakata yang berasal dari bahasa Inggris sehingga tuturan tersebut mengalami campur kode keluar, karena kata name-tags berasal dari variasi bahasa asing. Tujuan penutur melakukan campur kode keluar karena untuk mencari padanan yang tepat. Menurut pengamatan peneliti di lapangan menunjukkan bahwa peristiwa campur kode yang terjadi di lingkungan masyarakat pesantren merupakan hal yang biasa terjadi dalam komunikasi sehari-hari. Selain peristiwa campur kode, percakapan tersebut terdapat peristiwa alih kode dari bahasa Indonesia ke dalam bahasa Inggris. Hal ini bertujuan meningkatkan kompetensi dalam berbahasa asing.Pokok 
Eka Susylowati: Pilihan Kode dalam Interaksi Belajar-Mengajarsebagai Upaya Meningkatkan Kesepahaman Antaretnik

pembicaraan dalam tuturan tersebut mengenai name-tags yang harus dipakai oleh para santri di lingkungan Pesantren Modern Islam Assalaam.

\section{Data Tuturan (5)}

Konteks situasi: Percakapan antara santri 1 dan santri 2 pada saat santai di dalam kelas sebelum mata pelajaran dimulai, santri tersebut bermaksud untuk mengadakan kegiatan rapat untuk kegiatan outbond.

Santri 1 :"Nanti jam 2 siang ada rapat dulu dengan ustazah di ruang kesantrian untuk membicarakan outbond ke Sekipan."

Santri 2 :"Kok awan ya, porangantuk?"

Santri 1 :"lha piye padha isone ya jam loro"

Santri 2 :"yo wislah, sing penting suk minggu outbond nggo refreshing. Tugase akeh tenan kok."

Santri 1 :"Jadi santri yo harus rajin belajar biar cita-citanya tercapai."

Santri 2 :“Okey bos, siaapp!”

Penggunaan bahasa Jawa di lingkungan Pesantren Modern Islam Assalaam maupun di Pesantren Islam AlMukmin Ngruki tampaknya tidak begitu dominan digunakan untuk berkomunikasi oleh santri wanita kepada ustazah, ustaz maupun karyawan.Namun, realitanya dalam kegiatan keagamaan seperti khotbah maupun pengajian dalam masyarakat banyak menggunakan bahasa Jawa. Oleh karena itu, lulusan santri seharusnya juga mempelajari bahasa Jawa mengingat setelah mereka lulus dari pesantren akan terjun di dalam kehidupan bermasyarakat untuk berdakwah maupun kegiatan bisnis, pendidikan dan lain sebagainya. Berdasarkan observasi, munculnya pilihan kode bahasa Jawa (BJ) yang berupa alih kode maupun campur kode tampaknya jarang ditemukan di lingkungan Pesantren
Pesantren Islam Al-Mukmin Ngruki dalam interaksi belajar-mengajar. Pilihan kode bahasa Jawa (BJ) sebagian besar mucul untuk menciptakan suasana yang akrab dan santai. Selain itu dalam percakapan tersebut terdapat campur kode bahasa Inggris seperti kata outbond dan refreshing. Alasan digunakan kosakata tersebut karena untuk mencari padanan yang tepat.

\section{Data Tuturan (6)}

Konteks situasi: Saat ustazah menanyakan mengenai PR kepada santrinya.

Ustazah:“Assalamu'alaikum

Warahmatullahiwabaratuh"

Santri : "Wa'alaikumussalam

Warahmatullahiwabaratuh"

Ustazah: "Kemarin ada PR tidak untuk ektrajurnalistik?"

Santri :"Ada,Ust., mengarang tentang indahnya kehidupan di pesantren."

Ustazah: "Sudah selesai yang mengarang?"

Santri:"Belum selesai,Ust. Kemarin ikut renang."

Ustazah: "Sekarang Ustazah akan menjelaskan tentang penulisan artikel populer, di pesantren sini, ada yang pernah mengirimkan karangan ke koran atau redaksi majalah $\mathrm{Al}$ Mukminun?"

Santri:“Sudah pernah, Ust. Tapi nggak pernah dimuat"

Ustazah: "Jangan putus asa, nulis terus sampai bisa dimuat."

Santri :"Tapi lebih enak ikut ekstramasak bisa langsung dimakan."

Ustazah: "Kalau extramasak hari apa?"

Santri:"Hari Selasa siang, Ust. Sehabis sholat dhuhur."

Ustazah: "Berarti besok ada.Kalian nggak suka extrajurnalistik ya?"

Santri :"Bukannya nggak suka,Ust.tapi kadang malas mikir, Ust."

Ustazah: "Ya udah.Besok kalian jadi chef handal saja." 
Santri :"Siap,Ust.Mau belajar masak."

Ustazah: "Besok mau masak apa?"

Santri: "Diajari masak donat kentang, Ust."

Ustazah: "Wah! Enak itu.Bisa Ustazah mau liat?"

Santri :"Iya. Besok datang saja, Ust. Abis dhuhur."

Peristiwa tutur tersebut terjadi pada saat interaksi belajar-mengajar di lingkungan Pesantren Islam Al-Mukmin Ngruki. Pilihan bahasa Indonesia informal digunakan untuk berkomunikasi antara ustazah dan santrinya. Hal ini terjadi karena hubungan antara ustazah dan santri yang sudah akrab sehingga keduanya sudah tidak ada jarak sosial lagi. Setiap hari ustazah dan santri selalu bertemu dan bertegur sapa baik di kelas maupun di asrama sehingga keduanya memiliki kedekatan emosional. Pokok pembicaraan juga berubah yang tadinya serius menjadi santai.

\section{Data Tuturan (7)}

Konteks situasi: Percakapan antara santri 1 dan santri 2 pada saat santai di dalam kelas sebelum mata pelajaran dimulai.Santri tersebut bermaksud untuk meminjam catatan mahadharrah. Muhadharrah yaitu ceramah menggunakan tiga atau bahasa yaitu bahasa Indonesia, bahasa Inggris, dan bahasa Arab.

Santri 1 :"Kowe ndekwingi melu muhadharah pora?"

'Kamu kemarin ikut muhadharrah, tidak?'

Santri 2 :"Melu, tapi masalahe catatanku ora lengkap. Yo wis iki, silihen dhisik.".

"melu, tapi masalahnya catatan saya tidak lengkap. Ya sudah ini, dipinjam dulu'

Santri 1 :"Ya, makasih. Minggu depan temanya muhadharrah tentang apa?

Santri 2 :"Besuk mau diumumkan lagi, minggu depan mungkin muhadharrah kosong, arep ana kegiatan neng pondok." (ada kegiatan di pesantren)

Percakapan tersebut terjadi kelas pada saat situasi formal antara Santri 1 dan Santri 2 pada saat pelajaran. Dalam percakapan tersebut terjadi alih kode dari bahasa Jawa ke dalam bahasa Indonesia.Hal ini ditunjukkan dalam kalimat sebagai berikut. Santri 1: kowe ndekwingi melu muhadharah pora? Selanjutnya Santri 2 merespons tanggapan Santri 1 sebagai berikut Santri 2: "Melu, tapi masalahe catatanku ora lengkap. yo wis iki, silihen dhisik." Kemudian Santri 1 menanyakan kepada Santri 2 mengenai tema muhadharrah dengan menggunakan kode bahasa Indonesia yaitu Santri 1: ya, makasih. Minggu depan temanya muhadharah tentang apa? Selanjutnya, Santri 2 merespons dengan menggunakan bahasa Indonesia yaitu besuk mau diumumkan lagi, minggu depan mungkin muhadharrah kosong, arep ana kegiatan neng pondok (ada kegiatan di pesantren). "Dalam hal ini, alih kode dari bahasa Jawa ke dalam bahasa Indonesia digunakan karena terpengaruh aturan bahasa yang digunakan dalam lingkungan pesantren. Perlu diketahui di pesantren, para santri diwajibkan menggunakan bahasa Indonesia dalam interaksi sehari-hari atau menggunakan bahasa asing (Inggris dan bahasa Arab). Apabila menggunakan bahasa daerah, seperti bahasa Jawa akan dikenakan sanksi dari pesantren. Akan tetapi, realitanya, banyak santri yang menggunakan bahasa Jawa dalam berkomunikasi sehari-hari apabila sudah akrab dan berasal dari etnis Jawa.Selain itu, Pesantren Modern Islam Assalam dan Pesantren Islam Al-Mukmin Ngruki terletak di Provinsi Jawa Tengah sehingga bahasa Jawa digunakan sebagai media komunikasi sehari-hari.

\section{Bentuk Pilihan Kode}

Pesantren Modern Islam Assalaam dan Pesantren Islam Al-Mukmin Ngruki merupakan salah satu bentuk masyarakat 
Eka Susylowati: Pilihan Kode dalam Interaksi Belajar-Mengajarsebagai Upaya Meningkatkan Kesepahaman Antaretnik

yang menggunakan variasi bahasa yang beranekaragam dalam media komunikasi sehari-hari baik dalam situasi formal maupun informal. Bentuk bahasa yang sering digunakan dalam interaksi sosial yaitu bahasa Indonesia, bahasa Inggris, bahasa Arab, dan kadang bahasa Jawa. Berdasarkan empat bahasa yang digunakan, para santri sudah memenuhi syarat untuk diklasifikasikan ke dalam masyarakat multilingual karena sudah menggunakan lebih dari satu atau dua bahasa pada waktu berkomunikasi antara penutur dan mitra tutur.

Pilihan kode dalam interaksi belajar-mengajar di lingkungan Pesantren Modern Islam Assalaam dan Pesantren Islam Al-Mukmin Ngruki lebih dominan menggunakan bahasa Indonesia. Hal ini untuk memudahkan dalam memberikan materi pelajaran, namun para guru atau ustazah tetap mewajibkan penggunaan bahasa asing (Inggris maupun Arab) karena untuk meningkatkan kompetensi berbahasa asing agar santri mampu bersaing di tingkat regional maupun internasional.Sementara itu, bahasa Jawa bagi santri jarang digunakan sebagai media komunikasi karena lingkungan Pesantren Modern Islam Assalaam dan Pesantren Islam Al-Mukmin Ngruki melarang para santrinya untuk berkomunikasi dengan bahasa daerah. Akan tetapi, beberapa santri banyak yang melanggar aturan tersebut dengan menggunakan bahasa Jawa karena hubungan santri tersebut sudah akrab.

\section{PENUTUP}

Penelitian mengenai pilihan kode dalam interaksi belajar-mengajar tidak dapat dilepaskan dari latar belakang sosial pesantren. Berdasarkan hasil analisis dat, ditemukan sejumlah pilihan kode sebagai berikut bahasa Indonesia, bahasa asing
(Inggris dan Arab), bahasa Jawa, bahasa campur (BC) yaitu alih kode bahasa Jawa ke dalam bahasa Indonesia, maupun campur kode dari bahasa Jawa ke dalam bahasa Inggris. Alasan masyarakat pesantren di Pesantren Modern Islam Assalaam dan Pesantren Islam Al-Mukmin Ngruki melakukan alih kode maupun campur kode dalam interaksi belajarmengajar yaitu untuk memudahkan komunikasi dalam pembelajaran di kelas, menjalin keakraban, meningkatkan kompetensi bahasa asing, untuk mencari padanan yang tepat, aturan di lingkungan pesantren, perubahan topik pembicaraan Masih terbuka lebar bagi peneliti selanjutnya sehingga membuka peluang untuk melakukan penelitian di lingkungan pesantren yang dilihat dari kajian yang berbeda seperti etnolinguistik, pragmatik, maupun komunikasi.

\section{DAFTAR PUSTAKA}

Abdul, C. \& L. A. (2003). Sosiolinguistik Perkenalan Awal. Jakarta: Rineka Cipta.

Al-hourani, A., \& Afizah, T. N. (2013). Code switching in daily conversation. International Journal of Social Science and Humanities Research, $1(1), 40-43$.

Darmawati. (2013). ALIH KODE DALAM KONTEKS PERCAKAPAN GURU DI MAN 3 MAKASSAR ( Code Switching in Teachers Conversation in MAN 3 Makassar ). In Kandai (Vol. 9).

Faiz, A. (2018). Code-Switching Used By Sacha Stevenson in Talk Shows. Suar Betang, 12(2), 209. https://doi.org/10.26499/surbet.v12i2. 32

Halim, N. S., \& Maros, M. (2014). The Functions of Code-switching in Facebook Interactions. Procedia Social and Behavioral Sciences, 118, 126-133. 
https://doi.org/10.1016/j.sbspro.2014. 02.017

Harun, K., \& Yusof, M. (2015). Komunikasi Bahasa Melayu-Jawa dalam Media Sosial (Malay-Javanese Communication in Social Media). Jurnal Komunikasi, Malaysian Journal of Communication, 31(2), 617-629.

https://doi.org/10.17576/jkmjc-20153102-35

Holmes, J. (2001). An Introduction to Sociolinguistics. USA: Routledge.

Hymes, D. (2012). Dell Hymes - S. Ethnography of Communication.

Jaafar, M. F., Awal, N. M., Mis, M. A., \& Lateh, N. (2016). The patterns of language choice at the border of Malaysia-Thailand. Indonesian Journal of Applied Linguistics, 5(2), 176-185.

https://doi.org/10.17509/ijal.v5i2.134 2

Khaerunnisa, L. (2016). An EFL Teacher's Code Switching in a Young Learners' Class. Indonesian Journal of EFL and Linguistics, 1(1), 13-31. https://doi.org/10.21462/ijefll.vli1.1

Maros, M., Mohd Noorizan, N. D. M., \& Zakaria, A. H. I. (2016). Code Switching as The Medium of Solidarity in 'Ola Bola.' Jurnal Komunikasi, Malaysian Journal of Communication, 32(2), 1-28. https://doi.org/10.17576/jkmjc-20163202-01

Maryam, S. (2019). Pola bahasa generasi milenial dalam novel catatan hati seorang istri karya Asma Nadia. Genta Bahtera, 5(1), 46-55.

Mustikawati, D. A. (2016). Code-Mixing and Code Switchingin The Process of Learning. Register Journal, Vol. 9, p. 24.

https://doi.org/10.18326/rgt.v9i1.517

Rokhman, F. (2013). Sosiolinguistik: Suatu Pendekatan Pembelajaran Bahasa dalam Masyarakat Multikultural. Yogyakarta: Graha Ilmu.

Sa'adiah Ma'alip. (2015). PEMILIHAN
BAHASA DALAM KOMUNIKASI DI LAMAN SOSIAL. Jurnal Komunikasi, 31(2), 231-246.

Sabti, A. A., Rashid, S. M., \& Turki, H. Y. (2019). Code-switching between informal Iraqi dialect and English languageamongiraqiarabspeakersviaw hatsAppapplication: Linguistic and non-linguistic factors. Pertanika Journal of Social Sciences and Humanities, 27(3), 1431-1450.

Santosa, R. (2017). Metode Penelitian Kualitatif. Surakarta: Universitas Sebelas Maret Press.

Sayama Malabar. (2012). Penggunaan

Bahasa Transmigran Jawa Di Kabupaten Gorontalo. Humaniora, 24(3), 279-291. https://doi.org/10.22146/jh.v24i3.137 0

Suandi, N. (2014). Sosiolinguistik. Yogyakarta: Graha Ilmu.

Sudaryanto. (2015). Metode dan Aneka Teknik Analisis Bahasa. Yogyakarta: Sanata Dharma University Press.

Thesa, K. (2017). PENGGUNAAN ALIH KODE DALAM PERCAKAPAN PADA JARINGAN WHATSAPP OLEH MAHASISWA KNB YANG BERKULIAH DI UNIVERSITAS SEBELAS MARET. PRASASTI: Journal of Linguistics, 2(1), 89-101.

Wahidah, B. Y. K., Djatmika, D., \& Marmanto, S. (2017). Pilihan Kode Bagi Siswa Di Pesantren Ulil Albab (Kajian Sosiolinguistik). PRASASTI: Journal of Linguistics, 2(2), 173. https://doi.org/10.20961/prasasti.v2i2. 12222

Wardhaugh, R. (2006). An Introduction to Sociolinguistics Blackwell Textbooks in Linguistics. In Religion. https://doi.org/10.1353/lan.2003.0268 Yulia Mutmainah. (2008). Pemilihan Kode Dalam Masyarakat Dwi Bahasa: Kajian Sosiolinguistik Pada Masyarakat Jawa Di Kota Bontang Kalimantan Timur. UNDIP, Semarang. 